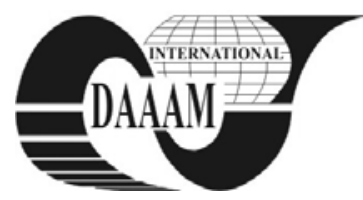

AAM for 2011 \& Proceedings of the 22nd International DAAAM Symposium, Volume 22, No. 1, ISSN 1726-9679 1509-83-4, Editor B. Katalinic, Published by DAAAM International, Vienna, Austria, EU, 2011

\title{
A POSSIBILITY OF SOCIAL INCLUSION BY RESPONSIBLE ENTREPRENEURSHIP IN SLOVAKIA
}

\author{
SMIDA, L[ubomir]; HRDINOVA, G[abriela]; SAKAL, P[eter] \& SYC, M[arek]
}

\begin{abstract}
The paper deals with the analysis of radical concepts of responsibility and their benefits in terms Vision 2050. By the analysis of concepts and subsequent synthesis, there is highlighted the potential of creation of a social responsibility business concept of glocal character. The main purpose of the work is a demonstration of the creation of social inclusion and opportunities to develop socially responsible business practices towards the socially excluded communities in the Slovak republic.

Key words: inclusion, responsibility, sustainability, value
\end{abstract}

\section{INTRODUCTION}

Since the early 90s when the World Business Council for Sustainable Development (WBCSD) was formed, there is a rapid increase in the effort to direct human activities on the path of sustainability and responsibility. Currently this is done through Vision 2050. A key factor in the success of Vision 2050 is to address the question of who should be the initiator of transformational change. These can be done only by applying systematic practices that will address the development of wider society. Cooperation requires trust between all segments of the population, including Socially Excluded Communities (SEC).

\section{VISION 2050}

Global society has reached a stage in which exists countless evidence of incorrect direction of human action.Due to the continuous increase of the number of planet's population, consumption of scarce resources grows and also increasingly grows the rate of destruction of ecosystems and society. An alternative picture of the year 2050 outlines WBCSD through the Vision 2050.

This new global status indicates that the main alternative to building a sustainable world by mid-century is the cooperation on local and regional levels among private and public sector, including entrepreneurship, government and civilians. People need to understand the uniqueness and richness of entrepreneurship, without which they cannot be successful (****, 2011).

\section{RADICAL CONCEPTS OF RESPONSIBILITY}

Taking responsibility for own actions is a critical success factor of future development of entrepreneurship.It means meet the legal requirements of the state, on the other hand integrate practices of social responsibility in entrepreneurship, beyond law.The philosophy of social responsibility is adapted in several forms. Over the past ten years was applied and got into the awareness of enterprises in particular the concept of Corporate Social Responsibility (CSR).

The incentive in this area is the emergence of new concepts, based on the philosophy of CSR, which radically change the philosophy of a business management and require a systematic approach.

\subsection{Creating Shared Value}

The notion of Creating Shared Value(CSV) presented by Michael Porter and Mark Kramer means the concept based on the principle of policy making and implementation of practices that allows you to create economic value for business and social value for society at the same time addressing the needs and problems. CSV is based on previously overlooked opportunities that come out from new customer needs, products and markets, the new definition of productivity in the value chain and cooperation for reinforcing the development of local clusters (Kramer et al., 2011).

The perspective of corporate sustainability is hidden in trust, which cannot be based on a great image. A prerequisite for success is the mutual support of all stakeholders, which reveals the philosophy of business and possible pursuit of quick enrichment.

The exemplary implementers of CSV practices are now companies like Nestlé, Western Union, and Cisco (Kramer et al., 2011). Positive example in the Slovak Republic (SK) is the project of U.S. Steel Košice about integration of Roma people into the work process.

The two main differences between the concept of CSR and CSV (Kramer, 2011):

1) CSR addresses the redistribution of money collected. It is seen as a cost centre, not as a profit centre. CSV deals with new business opportunities that are created by new markets, improving profitability and strengthen competitive position. 2) CSR is about responsibility. CSV is about value creation.

Many of the CSV characteristics can be found in "Bata management system" and the concept of"the bottom of the pyramid" promoted by C. K. Prahalad.

\subsection{Corporate Sustainability and Responsibility}

The notion of Corporate Sustainability and Responsibility (CSR 2.0) is a concept whose essence lies in making a positive impact on society. Sense of the concept is in designing and adaptation the business model of sustainability and responsibility (Visser, 2010).

The author of the concept, Wayne Visser, draws attention to the five ages of the development of social responsibility (Visser, 2010):

1) The Age of Greed.

2) The Age of Philanthropy.

3) The Age of Misdirection.

4) The Age of Management.

5) The Age of Responsibility.

Significant difference in the understanding of social responsibility is the application of a systematic approach within the business, which lacks the first four ages. CSR 2.0 is located in the core of the business, what is the main difference from the CSR. Model of the concept of CSR 2.0 is inspired by the human DNA.

CSR 2.0DNA code consists of four elements, namely, value creation, good governance, social contribution and environmental integrity (Visser, 2011). The success of the 
transition from CSR to CSR 2.0 requires the integration of new principles underlying DNA of CSR 2.0 (Visser, 2010):

1) Creativity.

2) Scalability.

3) Responsiveness.

4) Glocalization.

5) Circularity.

Projects that partially meet the principles of CSR 2.0 are known mostly in developing countries, such as banking service M-PESA, a car Tata Nano.

CSR 2.0, as well as CSV concept contributes to the fulfilment of Vision 2050. Both radically change the core of the business, which enables enterprises to implement practices tend to raising social and environmental well-being. By linking the two concepts, there can be global localized (globalized) the potential of application of concepts in states, slowly acceding to taking responsibility for their actions. These states include the SR.

\section{SYNTHESIS OF RADICAL CONCEPTS IN THE SLOVAK REPUBLIC}

The SK approach to address sustainable development issues is reactive. Expect adoption of commitments at European Union (EU) level and then take measures on its own terms. The strategy of Europe 2020 had the same expression in Slovakia. However, positive in the area is the effort to reduce the population at risk of poverty or social exclusion.

Tendencies of current government in the SK led to the approval of the law about the SEC, which will aim to create systematic solutions in order to improve the living conditions of SEC in accordance with the principles of motivation, merit and individual responsibility for their welfare $(* * *, 2011)$.There are several documents within the EU and SK, which allow understanding and applying solutions based on mutual benefit between business and society, Europe 2020 strategy, An EU Framework for National Roma Integration Strategies, Slovak National Strategic Reference Framework. The key question is raising awareness of social responsibility so that enterprises understand the need to change the entrepreneurship prospects.

Given that facts, we suggest starting points for creating the concept of social responsibility based on radical concepts of responsibility of glocal character:

1) Sustainability as a goal.

2) Responsibility as a way of achieving goal.

3) Mutually beneficial cooperation.

4) Cooperation within the cluster.

5) Creating new jobs by expansion into new markets.

6) Production of new products oriented to low-income groups.

7) Quick expandable solutions.

8) Support for creative people.

9) Application of the philosophy of "cradle to cradle."

10) Sustainable and at the same time legitimate profit.

Aim is to establish practices that will come out from the core of the business, and that will promote the proper functioning of the economy and not focus only on profit.

\section{SOCIAL INCLUSION}

An important role within the process of social unificationplaysan entrepreneurship. By integration of SEC to work process there is an increase of the chances of building working habitsthat will lead to individual responsibility and understanding the need to develop their own individuality in favour of whole society.

The base of the integration, for us, is building social enterprises, by the government, aimed at creating jobs in low value added. Social inclusion requires the creation of conditions that lead to new opportunities and access to an indispensable source of life.
An entrepreneurship is able to motivate SEC to higher performance by support in education and integration into own working process. It is therefore necessary to specify the core of the business and adapt to new conditions by integration of a radical approach to social responsibility. For a business whose core is based on sustainability and responsibility will be the norm to enter into cooperation with SEC. The starting point of cooperation is to understand their situation and cooperation with government and NGOs in the process of addressing issues of poverty.

The new approach to SEC requires application of policies that promote sustainability of social inclusion. For short-term solutions and return back to the conditions of poverty would drastically increase the reluctance of SEC to take measures to reverse the negative situation. The aim of social inclusion is to achieve a normal level of prosperity within a particular local community and the related participation in sustainable development. Linking all citizens, society gets on the path of Vision 2050.

\section{CONCLUSION}

Radical concepts of responsibility paved the way for solving many issues of social unification. SEC integration into the work process will increase the dynamics of the process by harnessing new capabilities. In this work we show on glocal approach, when new global solutions are locally applied. In the SK, there is a prerequisite for successful development, solution the substance of the problems associated with social inclusion.

The next step will be a specification ofbusiness philosophy through the implementation of the philosophy of sustainability and responsibility into the core of the business, definition of possibilities in building up social enterprises from the state and the subsequent incorporation of individual subjects among the SEC in the business, into the long-term adaptable people.

\section{ACKNOWLEDGEMENTS}

This paper was supported by the Slovak Research and Development Agency underthe contract No. LPP-0384-09: "Concept HCS model 3E vs. Concept Corporate SocialResponsibility (CSR)." The paper is also a part of submitted KEGA project No. 037STU-4/2012 "Implementation of the subject "Corporate Social Responsibility Entrepreneurship”into the study programme Industrial management in the second degree at MTF STU Trnava."

\section{REFERENCES}

Kramer, M.; et al.(2011).Creating Shared Value -Roundtable, Available from:http://www.youtube.com/ watch?v=VSSx 9HDgvt8Accessed: 2011-09-14

Kramer,M.(2011),CSR vs. CSV - What's thedifference?,Availablefrom:http://www.fsg.org/Knowledg eExchange/Blogs/CreatingSharedValue/PostID/66.aspx Accessed: 2011-09-18

Visser, W. (2010).From the Age of Greed to the Age of Responsibility, Available from:http://www.waynevisser.com/chapter_age_responsibil ity.pdf Accessed:2011-09-19

Visser, W. (2011).The DNA Model of CSR 2.0, Available from:http://www.waynevisser.com/inspiration_dna_model_ csr_visser.pdf Accessed:2011-09-19

*** (2011) http://www.employment.gov.sk/index.php?SMC= 1\&mod=news\&nid=756\&lg=sk - MPSVR, Tlačováspráva, Accessed on: 2011-09-14

*** (2011) http://www.wbcsd.org/DocRoot/ 9hSGwxf2cX5D ULniplTL/wbcsd_annualReview2010-11.pdfWBCSD,Annual review, Accessed on: 2011-09-10 